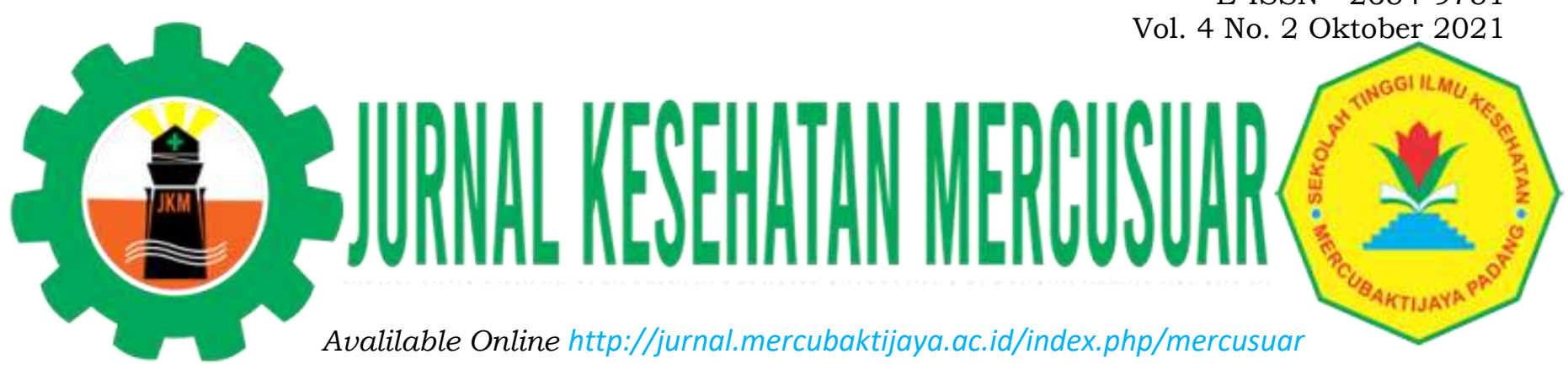

\title{
HUBUNGAN TINGKAT KECEMASAN DENGAN SIKLUS MENSTRUASI PADA MAHASISWI TINGKAT AKHIR
}

\author{
Veronica Silalahi ${ }^{1 *}$ \\ ${ }^{1}$ STIKES Katolik St.Vincentius a Paulo Surabaya, Jalan Jambi 12-18 \\ *Email korespondensi : vero.silalahi30@gmail.com
}

\begin{abstract}
Menstruation is a natural process in every woman and repeats itself every month. Irregular menstrual cycles are one of the signs of menstrual disorders and can be caused by anxiety. The phenomenon found in 10 female students with the final task has anxiety and the menstrual cycle is not normal. This study's aim to analyzed the relationship anxiety levels and the late-level menstrual. The research method is quantitative with a correlation study, design with a cross sectional. The research sample is a final-level students of Catholic School of Health Sciences of St.Vincentius a Paulo, Surabaya with 56 respondents. Sampling technique using Simple Random Sampling. Anxiety levels were measured by the Psychometric Properties of The Depression Anxiety Stress Scale 42 questionnaire (DASS 42) and the menstrual cycle by the menstrual cycle questionnaire. The results showed 38\% very severe anxiety, $23.2 \%$ no anxiety, $19.6 \%$ severe anxiety, $12.5 \%$ moderate anxiety, $7.1 \%$ mild anxiety, and $61 \%$ normal menstrual cycles. Correlation test result showed $p=0.098(p>0.05)$ which means there is no relationship between anxiety levels and menstrual cycles. Irregular menstrual can be caused by other factors such as weight, physical activity. College students can maintain a diet, regular exercise, and manage anxiety.
\end{abstract}

Keywords : Menstrual cycle, Anxiety level

\begin{abstract}
ABSTRAK
Menstruasi adalah proses yang alami pada setiap wanita dan berulang setiap bulan. Siklus menstruasi yang tidak teratur adalah salah satu tanda gangguan menstruasi dan dapat disebabkan oleh kecemasan. Fenomena yang ditemukan pada 10 mahasiswi yang mengalami kecemasan dengan adanya tugas akhir dan siklus menstruasi tidak normal. Tujuan penelitian untuk menganalisis hubungan antara tingkat kecemasan dengan siklus menstruasi. Metode penelitian secara kuantitatif dengan desain penelitian studi korelasi dengan pendekatan cross sectional. Sampel penelitian adalah mahasiswi tingkat akhir Stikes Katolik St. Vincentius A Paulo Surabaya sebanyak 56 responden. Teknik sampling menggunakan Simple Random Sampling. Tingkat kecemasan diukur dengan kuisioner Psychometric Properties of The Depression Anxiety Stres Scale 42 (DASS 42) dan siklus menstruasi dengan kuisioner siklus menstruasi. Analisa data dengan uji rank spearman. Hasil penelitian menunjukkan 38\% memiliki tingkat kecemasan sangat berat, 23.2\% tidak ada kecemasan, $19.6 \%$ tingkat kecemasan berat, $12.5 \%$ tingkat kecemasan sedang, $7.1 \%$ tingkat kecemasan ringan dan $61 \%$ responden memiliki siklus menstruasi normal. Hasil uji korelasi menunjukkan nilai $\mathrm{p}=0,098(\mathrm{p}>0,05)$ yang berarti tidak ada hubungan antara tingkat kecemasan dengan siklus menstruasi. Siklus menstruasi yang tidak normal bisa disebabkan oleh faktor lain seperti berat badan, aktivitas fisik. Mahasiswi dapat menjaga pola makan, teratur berolahraga dan mengelola kecemasan.
\end{abstract}


Kata kunci : Siklus menstruasi, Tingkat kecemasan

\section{PENDAHULUAN}

Menstruasi atau biasa disebut haid adalah suatu proses yang alami yang terjadi pada wanita. Menstruasi merupakan proses lepasnya dinding rahim yang diikuti oleh perdarahan yang terjadi berulang disetiap bulan dan akhirnya membentuk siklus menstruasi (Meilan \& Fillona, 2018). Waktu normal siklus menstruasi berkisar antara 2135 hari dengan lama menstruasi yang berkisar antara 3-7 hari dan selama menstruasi berlangsung jumlah darah tidak lebih $>80 \mathrm{ml}$ dengan frekuensi penggantian pembalut 2-6 kali/hari (Harzif et al., 2018). Siklus haid dikatakan tidak normal apabila siklusnya $<21$ hari dan $>35$ hari (Sinaga et al., 2017).

Siklus menstruasi memiliki variasi, seperti variasi keadaan serta lama durasi yang setiap alami saat menstruasi. Variasi yang masih dalam batas normal yang disebut sebagai variasi fisiologis sedangkan variasi yang sudah di luar batas normal, disebut sebagai variasi patologis dimana bisa disebut sebagai suatu gangguan menstruasi (Andrews, 2010). Dikatakan sebagai gangguan bila karakteristik menstruasinya mengalami perubahan, seperti siklus tidak teratur, nyeri yang berlebihan, menstruasi yang waktunya menjadi lebih lama, serta darah menstruasi yang menjadi lebih banyak (Wirenviona \& Riris, 2020).

Siklus menstruasi yang tidak teratur adalah salah satu dari tanda adanya gangguan menstruasi, Gangguan menstruasi disebabkan oleh beberapa faktor yaitu faktor psikologis (stres, tekanan hidup, kecemasan dan kelelahan fisik maupun psikis), gangguan hormonal, status gizi, dan kelainan organik (radang tumor, trauma) dan sebagainya (Wirenviona \& Riris, 2020). Kecemasan menjadi satu faktor yang menyebabkan adanya gangguan menstruasi pada wanita yang menjadi fenomena universal dimana setiap orang pasti mengalaminya dan akan memberi dampak pada fisik, emosi, sosial dan spiritual (Wirenviona \& Riris, 2020). Menyelesaikan tugas akhir bukanlah hal yang mudah, oleh sebab itu, penulisan tugas akhir dianggap sebagai tugas yang berat bagi setiap mahasiswa tingkat akhir (Sudarya, 2014). Hasil penelitian yang dilakukan oleh (Devi et al., 2015) tentang tingkat kecemasan pada mahasiswa D3 tingkat 3 didapatkan data bahwa sebanyak 10 responden $(24,4 \%)$ dan mahasiswi yang mempunyai tingkat kecemasan berat sebagian besar mengalami siklus menstruasi yang tidak teratur sebanyak 6 responden $(14,46 \%)$. Hasil penelitian dari (Purwati \& Muslikhah, 2020) didapatkan data bahwa 30 mahasiswa semester 7 $(46,88 \%)$ mengalami siklus mestruasi tidak teratur.

Berdasarkan survey data secara online pada mahasiswi tingkat akhir di Stikes St. Vincentius A Paulo Surabaya, didapatkan mahasiswa memiliki kecemasan akibat tugas yang banyak dan harus diselesaikan yaitu salah satunya adalah tugas akhir seperti skripsi dan KTI, dan juga diantara mereka mengalami menstruasi mereka teratur dan juga mengalami siklus menstruasi yang tidak teratur (55 hari, 53 hari, 43 hari, 40 hari, 42 hari dan 60 hari).

Mahasiswa tingkat akhir, pada umumnya menemui beberapa kesulitan seperti kegagalan mencari judul skripsi, kesulitan untuk menulis, kesulitan mencari literatur, kurang ketertarikan mahasiswa pada penelitian, serta kesulitan menemui dosen pembimbing, mereka juga dituntut untuk bisa dewasa dalam tindakan serta pemikiran karena semakin tinggi pendidikan, maka semakin tinggi juga tekanan yang dihadapi. Dampak dari kesulitan-kesulitan yang dialami mahasiswa tersebut akan berkembang menjadi perasaan negatif 
sehingga dapat menimbulkan ketegangan, frustasi, rendah diri, kekhawatiran, dan kehilangan motivasi juga dapat menimbulkan kecemasan (Afryan et al., 2019).

Kecemasan mengakibatkan perubahan sistemik dalam tubuh khususnya pada sistem saraf. Kecemasan memicu lepasnya hormon kortisol dimana hormon kortisol akan menekan hipotalamus dan mengganggu kerja dan fungsi hipotalamus, yang salah satunya adalah mensekresi hormon menstruasi follicle stimulating hormone (FSH) dan luetinizing hormone (LH). Terjadi perubahan prolaktin atau endogeneous opiat yang memengaruhi elevasi kortisol basal sehingga menurunkan hormon LH. Apabila terjadi gangguan pada hormon LH dan FSH, maka akan mempengaruhi produksi estrogen dan progesterone sehingga akan menyebabkan ketidakteraturan siklus haid (Kusmiran, 2014). Gangguan siklus menstruasi juga menjadi suatu tanda penting yang menunjukan adanya gangguan pada sistem reproduksi yaitu peningkatan risiko berbagai penyakit seperti kanker rahim, kanker payudara dan infertilitas (Kusmiran, 2014).

Upaya yang dapat dilakukan agar mencegah terjadinya gangguan siklus menstruasi salah satunya dengan berolahraga, namun tidak berlebihan. Olahraga yang berlebihan dapat menyebabkan terjadinya disfungsi hipotalamus yang menyebabkan gangguan sekresi GnRH (Gonadotropin Releasing Hormone). Penekanan hormon GnRH yang dihasilkan dari disfungsi hipotalamus terkait olahraga mengganggu pola siklus menstruasi dengan membatasi sekresi Luteinizing Hormone (LH) dan Follicle Stimulating Hormone (FSH) (Ahrens et al, 2014 dalam Wahyuni et al., 2018). Selain aktivitas fisik, yang dapat dilakukan mahasiswa adalah memperkuat gaya hidup dengan gizi yang baik. Status gizi pada perempuan ketika dalam kondisi kelebihan maupun kekurangan dapat menyebabkan fungsi hipotalamus menurun sehingga tidak memberikan stimulasi kepada hipofisis anterior untuk mengekskresi FSH Stimulating Hormone) dan LH yang mengakibatkan kadar hormon esterogen mengalami penurunan sehingga berdampak negatif pada siklus menstruasi yaitu menghambat terjadinya proses ovulasi dan menyebabkan terjadinya pemanjangan siklus menstruasi (Dya \& Adiningsih, 2019).

\section{METODE PENELITIAN}

Desain penelitian menggunakan studi korelasional dengan pendekatan cross sectional. Populasi penelitian ini adalah mahasiswi tingkat akhir di STIKES Katolik St.Vincentius a Paulo Surabaya dengan kriteria inklusi mahasiswi tingkat akhir (Prodi Ilmu Keperawatan, Keperawatan dan Fisioterapi ) di Stikes ST.Vincentius A Paulo Surabaya yang bersedia dan setuju menandatangai lembar persetujuan untuk menjadi responden, sebelum mengerjakan tugas akhir tidak mengalami gangguan siklus mentruasi. Pemilihan sampel dengan simple random sampling dan jumlah responden sebanyak 56 orang.

Pengumpulan data penelitian menggunakan kuesioner yang dibagikan secara online melalui google form yang dibagikan ke grup kelas masing-masing serta penjelasan tertulis tentang maksud dan tujuan penelitian ini dilakukan. Untuk kecemasan menggunakan kuisioner Psychometric Properties of The Depression Anxiety Stres Scale 42 (DASS 42) yang berisi 14 pertanyaan dan siklus menstruasi dengan kuisioner siklus menstruasi. Analisis data dengan menggunakan uji rank spearman dengan $\mathrm{p}<\alpha(\mathrm{p}=0.05)$. 


\section{HASIL DAN PEMBAHASAN}

Tabel 1. Karakteristik Responden Berdasarkan Data Umum Variabel Tingkat Kecemasan dan Siklus Menstruasi Pada Mahasiswi Tingkat Akhir

\begin{tabular}{lcc}
\hline \multicolumn{1}{c}{ Karakteristik } & f & \% \\
\hline $\begin{array}{l}\text { Dukungan teman sebaya } \\
\text { Ya }\end{array}$ & 56 & 100 \\
Tidak & & \\
Pengalaman tidak menyenangkan selama mengikuti & & \\
pembelajaran tingkat akhir & 20 & 35.7 \\
Ya & 36 & 64.3 \\
Tidak & & \\
Lingkungan keluarga mendukung selama proses belajar & & \\
Ya & 56 & 100 \\
Tidak & & \\
Lingkungan sosial mendukung proses pembelajaran & 56 & 100 \\
Ya & & \\
Tidak & & \\
Motivasi diri sendiri dalam proses pembelajaran & 54 & 96.4 \\
Ya & 2 & 3.6 \\
Tidak & & \\
Berat badan & & 21.4 \\
Kurus & 12 & 39.3 \\
Normal & & 14.3 \\
Overweight & 22 & 8.1 \\
Obesitas 1 & & \\
Obesitas 2 & 8 & 55.4 \\
Aktivitas fisik olahraga 1x dalam seminggu & 9 & \\
Ya & 5 & \\
Tidak & & \\
\hline
\end{tabular}

Dari tabel 1 didapatkan data dari 56 responden, ada 43 responden $(76.8 \%)$ mengalami usia menarche <13 tahun, 56 responden $(100 \%)$ mendapat dukungan dari teman selama mengikuti pembelajaran, 36 (64.3\%) responden tidak memiliki pengalaman yang tidak menyenangkan selama mengikuti pembelajaran tingkat akhir, $56(100 \%)$ responden didapatkan lingkungan keluarga mendukung selama proses belajar, 56 (100\%) responden memiliki lingkungan sosial mendukung proses pembelajaran, 54 (96.5\%) responden memiliki motivasi diri sendiri dalam proses 
Veronica Silalahi | Hubungan Tingkat Kecemasan Dengan Siklus Menstruasi Pada Mahasiswi Tingkat Akhir

pembelajaran, $22 \quad(39.3 \%)$ responden tidak melakukan aktivitas fisik kurang 1 kali memiliki berat badan normal. $31(55.3 \%)$ dalam 1 minggu.

Tabel 2 Tingkat Kecemasan dan Siklus Menstruasi pada Mahasiswi Tingkat Akhir

\begin{tabular}{lll}
\hline Variable & f & \% \\
\hline Tingkat kecemasan & & \\
Tidak ada kecemasan & 13 & 23 \\
Kecemasan ringan & 4 & 7 \\
Kecemasan sedang & 7 & 12 \\
Kecemasan berat & 11 & 20 \\
Kecemasan sangat berat & 21 & 38 \\
Siklus Menstruasi & & \\
Normal & 34 & 61 \\
Tidak Normal & 22 & 39 \\
\hline
\end{tabular}

Berdasarkan tabel 2 diatas, dari tingkat kecemasan didapatkan data bahwa dari 56 responden ada $21(38 \%)$ responden memiliki tingkat kecemasan sangat berat, $13(23 \%)$ responden tidak ada kecemasan, 11 (20\%) responden memiliki tingkat kecemasan berat, $7(12 \%)$ responden memilikit tingkat sedang, dan $4(7 \%)$ responden memiliki tingkat kecemasan ringan. Ditinjau dari siklus menstruasi, didapatkan data dari 56 responden ada $34(61 \%)$ responden memiliki siklus menstruasi yang normal, dan 22 (39\%) responden memiliki siklus menstruasi yang tidak normal.

\section{Tingkat Kecemasan}

Berdasarkan hasil penelitian, didapatkan data bahwa $21(38 \%)$ responden memiliki tingkat kecemasan sangat berat, 13 (23.2\%) responden tidak ada kecemasan, 11 $(19.6 \%)$ responden memiliki tingkat kecemasan berat, $7(12.5 \%)$ responden memilikit tingkat sedang, dan $4(7.1 \%)$ responden memiliki tingkat kecemasan ringan. Ditinjau dari pengalaman yang tidak menyenangkan selama mengikuti pembelajaran semester akhir, didapatkan 8 $(38.1 \%)$ responden memiliki kecemasan sangat berat. Menurut Stuart dan Laraia dalam (Sutejo, 2019), bahwa kecemasan berhubungan dengan adanya trauma atau adanya pengalaman yang tidak menyenangkan. Dalam hal ini, pengalaman yang tidak menyenangkan yang dialami mahasiswa selama mengikuti pembelajaran semester akhir, seperti kesulitan mencari referensi dalam menyelesaikan tugas akhir, banyak tugas sehingga sulit membagi waktu, pembelajaran online. Peneliti berpendapat bahwa terdapat kesesuaian antara fakta dan teori, dimana banyaknya tugas mahasiswa terutama semester akhir memicu kecemasan mahasiswa. Banyaknya tugas yang dikerjakan mahasiswa membuat mereka kesulitan membagi waktu dan memberikan tekanan tersendiri kepada mahasiswa. Hal ini juga sejalan dengan penelitian Lufthi \& Yaunin, (2020), bahwa kecemasan yang muncul pada mahasiswa tingkat empat disebabkan oleh banyak faktor yaitu padatnya jadwal perkuliahan, kegiatan tutorial, praktikum, skill laboratorium, dan tuntutan untuk belajar mandiri di luar jam kuliah. Oleh karena itu, tekanan dan beban kondisi fisik dan mental peserta didik lebih 
berat dibandingkan bidang pendidikan lainnya.

Peneliti juga berpendapat terdapat kesesuaian antara teori dengan fakta, yaitu mahasiswa tingkat akhir akan menemui berbagai macam kesulitan salah satunya adalah kesulitan dalam mencari referensi untuk penulisan tugas akhir, khususnya pada masa pandemi ini mahasasiwa memiliki beberapa kesulitan saat mencari literatur seperti sangat sulit menjangkau perpustakaan kampus karena jarak yang jauh, adanya batasan untuk datang kekampus dan peminjaman buku. Hal-hal inilah yang akan menghambat mahasiswi dalam penulisan tugas akhir dan akhirnya dapat menimbulkan kecemasan bagi mahasiswa. Hal ini didukung oleh penelitian yang dilakukan oleh Sawitri \& Widiasavitri, (2021) yaitu permasalahan yang menghambat proses pengerjaan tugas akhir responden adalah sulitnya mencari referensi. Tidak semua referensi yang dibutuhkan dapat diakses secara online, terdapat beberapa referensi buku yang hanya dapat diakses secara offline di perpustakaan. Perpustakaan menyediakan fasilitas peminjaman buku namun dengan jarak tempuh yang dekat, sedangkan posisi tempat tinggal responden melampaui jarak yang ditentukan sehingga responden tidak dapat mengakses fasilitas tersebut. Adanya hambatan inilah yang menjadi pemicu kecemasan yang dialami oleh mahasiswa.

Ditinjau dari dukungan dari teman, didapatkan data $13(100 \%)$ responden tidak mengalami kecemasan. Menurut Stuart dan Laraia dalam Sutejo, (2019), teman sebaya sangat berpengaruh pada kecemasan mahasiswa, karena teman sebaya merupakan orang terdekat dengan mahasiswa. Jika teman sebaya mahasiswa sering memberikan motivasi dalam proses pembelajaran akan mengurangi kecemasan yang dialami oleh mahasiswa. Terdapat kesesuaian antara fakta dan teori yaitu teman sebaya sebagai orang terdekat dengan mahasiswa dapat saling membantu, saling memotivasi dalam proses pembelajaran terutama saat tugas akhir, sehingga tugas bisa terselesaikan.

Namun, bila ditinjau dari dukungan dari keluarga, didapatkan data bahwa 21 $(100 \%)$ responden yang mendapat dukungan keluarga memiliki tingkat kecemasan sangat berat. Menurut Stuart dan Laraia dalam (Sutejo, 2019), lingkungan keluarga, keadaan rumah yang penuh dengan pertengkaran atau ketidakpedulian orang tua kepada anak dapat menyebabkan ketidaknyamanan dan rasa cemas, dan sebaliknya. Tidak terdapat kesesuaian antara fakta dan teori, dimana walaupun mahasiswa semester akhir sudah mendapat dukungan keluarga baik materi, psikologis, namun mereka masih merasakan kecemasan. Hal ini bisa disebabkan karena banyak mahasiswa yang tinggal jauh dari keluarga, dan mereka tinggal di kost karena mereka tidak bisa mendapatkan bantuan kapanpun mereka butuhkan karena tidak tinggal bersama dengan orangtua. Hal ini sejalan dengan penelitian yang dilakukan oleh Diferiansyah, (2015) dalam Lufthi \& Yaunin, (2020) bahwa seseorang yang tinggal terpisah dari keluarga selama masa kuliah sering mengalami persaingan akademik, masalah ekonomi, kesulitan mengatur waktu manajemen secara mandiri dan menjadi stressor bagi mahasiswa

\section{Siklus Menstruasi}

Pada variabel siklus menstruasi, bila ditinjau dari faktor berat badan, dari 34 responden $(100 \%)$ yang memiliki siklus menstruasi normal, terdapat $47,1 \%$ responden memiliki kategori Indeks Massa Tubuh (IMT) normal dan dari 22 responden (100\%) yang memiliki siklus menstruasi tidak normal, terdapat $40,9 \%$ responden memiliki kategori Indeks Massa Tubuh 
(IMT) kurus. Perubahan berat badan akan mempengaruhi fungsi menstruasi. Berat badan turun secara akut dan sedang akan mengakibatkan gangguan pada fungsi ovarium, Kondisi patologis seperti berat badan kurang akan menyebabkan penurunan berat badan sehingga dapat menyebabkan siklus menstruasi yang tidak teratur (Kusmiran, 2014). Peneliti berpendapat ada kesesuaian antara teori dengan fakta, yaitu responden yang mengalami siklus menstruasi yang tidak normal dipengaruhi oleh berat badan yang perubahan berat badannya secara tidak stabil yang dapat mempengaruhi siklus menstrusi. Berat badan yang kurang atau lebih akan mempengaruhi hormon-hormon pada tubuh sehingga akan mempengaruhi siklus menstruasi. Responden yang memiliki berat badan kurang akan beresiko mengalami siklus menstruasi yang tidak normal sedangkan berat badan normal cenderung memiliki siklus menstruasi yang teratur. Hal ini didukung oleh penelitian yang dilakukan oleh Hidayah et al., (2016) yaitu individu yang memiliki status gizi kurang akan mengalami hambatan dengan menstruasinya. Kehilangan berat badan secara besar-besaran dapat menyebabkan penurunan hormon gonadotropin untuk pengeluaran LH dan FSH yang mengakibatkan kadar estrogen akan turun sehingga berdampak negatif pada siklus menstruasi dan ovulasi (Hidayah et al., 2016). Status gizi yang kurang dapat menyebabkan anemia dan anemia sendiri dapat terjadi bila pola menstruasi tidak teratur (Sari, 2020).

Bila ditinjau dari faktor aktivitas fisik, berdasarkan hasil penelitian dari 22 responden $(100 \%)$ yang memiliki siklus menstruasi yang tidak normal, terdapat $81,8 \%$ responden menyatakan tidak melakukan olahraga minimal 1 minggu sekali dan dari 34 responden (100\%) yang memiliki siklus menstruasi normal, terdapat $61,8 \%$ responden menyatakan melakukan olahraga minimal 1 minggu sekali. Tingkat aktivitas fisik yang ringan dan berat dapat mempengaruhi menstruasi. Apabila aktivitas fisik dilakukan dengan intensitas sedang maka akan memberikan manfaat bagi kesehatan tubuh, khususnya pada kesehatan reproduksi (Afiyanti \& Pratiwi, 2017). Menurut peneliti ada kesesuaian antara teori dengan fakta yaitu aktivitas fisik merupakan salah satu faktor yang mempengaruhi ketidakteraturan menstruasi. Aktivitas fisik yang ringan seperti duduk, menonton televisi, dan bermain handpone akan meningkatkan resiko terjadinya menstruasi yang tidak normal karena aktivitas fisik yang ringan kurang membantu dalam proses metabolisme tubuh, sedangkan aktivitas fisik yang berlebihan atau berat juga akan mempengaruhi siklus menstruasi karena akan menurunkan level kadar esterogen. Jika aktivitas fisik dilakukan dalam intesitas sedang dengan olahraga minimal 1 minggu sekali, maka akan membantu proses metabolisme tubuh yang baik. Hal ini juga didukung oleh penelitian oleh hasil penelitian dari Purwati \& Muslikhah, (2020) yaitu aktivitas ringan akan meningkatkan cadangan energi di jaringan adiposa yang dapat menyebabkan defisit cadangan energi teroksidasi. Defisit cadangan teroksidasi akan berdampak pada siklus menstruasi sedangkan aktivitas fisik yang berat dapat menyebabkan terjadinya disfungsi hipotalamus yang menyebabkan gangguan pada sekresi Gonadotropin-releasing hormone $(\mathrm{GnRH})$ dan aktivitas gonadotropin sehingga menurunkan level dari serum estrogen, sehingga dalam hal ini aktivitas berat menyebabkan adanya gangguan siklus menstruasi (Purwati \& Muslikhah, 2020). 


\section{Tabel. 3 Hubungan Antara Tingkat Kecemasan dengan Siklus Menstruasi pada Mahasiswi Tingkat Akhir}

\begin{tabular}{lccccccc}
\hline \multicolumn{1}{c}{\begin{tabular}{c} 
Tingkat kecemasan \\
\multicolumn{1}{c}{ Responden }
\end{tabular}} & \multicolumn{2}{c}{ Normal } & \multicolumn{2}{c}{$\begin{array}{c}\text { Siklus Menstruasi } \\
\text { tidak normal }\end{array}$} & \multicolumn{2}{c}{ Total } & p-value \\
& $\sum$ & $\mathbf{\%}$ & $\sum$ & $\boldsymbol{\%}$ & $\sum$ & $\mathbf{\%}$ & \\
\hline Tidak ada kecemasan & 11 & 84.6 & 2 & 15.4 & 13 & 100 & 0,098 \\
Kecemasan Ringan & 4 & 100 & 0 & 0 & 4 & 100 & \\
Kecemasan sedang & 3 & 42.9 & 4 & 57.1 & 7 & 100 & \\
Kecemasan berat & 4 & 36.4 & 7 & 63.6 & 11 & 100 & \\
Kecemasan sangat berat & 12 & 57.1 & 9 & 42.9 & 21 & 100 & \\
\hline Total & $\mathbf{3 4}$ & $\mathbf{6 0 , 7}$ & $\mathbf{2 2}$ & $\mathbf{3 9 , 3}$ & $\mathbf{5 6}$ & $\mathbf{1 0 0}$ & \\
\hline
\end{tabular}

*Bermakna dengan $\mathrm{p}<0,05$

Berdasarkan tabel 3 diatas dari 21 responden yang memiliki tingkat kecemasan sangat berat, terdapat 12 responden $(57.1 \%)$ memiliki siklus menstruasi normal. Dari 13 responden yang tidak ada kecemasan, terdapat 11 responden $(84.6 \%)$ memiliki siklus menstruasi normal. Dari 11 responden yang memiliki tingkat kecemasan berat, terdapat 7 responden $(63,6 \%)$ memiliki siklus menstruasi yang tidak normal. Hasil uji rank spearman didapatkan $\mathrm{p}=0,098$ dengan nilai $\alpha=0,05$, dimana $\mathrm{p}<\alpha$ yang berarti tidak terdapat hubungan antara tingkat kecemasan dengan siklus menstruasi pada mahasiswi tingkat akhir di Stikes Katolik St.Vincentius A Paulo Surabaya.

Berdasarkan hasil tabulasi silang tingkat kecemasan dan siklus menstruasi, didapatkan bahwa 12(57.1\%) mahasiswa semester akhir yang mengalami kecemasan sangat berat, mengalami siklus menstruasi yang normal. Berdasarkan uji analisis rank spearman, didapatkan nilai $\mathrm{p}=0.098, \mathrm{p}>\alpha$, berarti tidak ada hubungan antara tingkat kecemasan dengan siklus menstruasi pada mahasiswa semester akhir. Menurut Kusmiran, (2014), kecemasan mengakibatkan perubahan sistemik dalam tubuh khususnya pada sistem saraf. Kecemasan memicu lepasnya hormon kortisol dimana hormon kortisol akan menekan hipotalamus dan mengganggu kerja dan fungsi hipotalamus, yang salah satunya adalah mensekresi hormon menstruasi follicle stimulating hormone (FSH) dan luetinizing hormone (LH). Terjadi perubahan prolaktin atau endogeneous opiat yang memengaruhi elevasi kortisol basal sehingga menurunkan hormon LH. Apabila terjadi gangguan pada hormon LH dan FSH, maka akan mempengaruhi produksi estrogen dan progesterone sehingga akan menyebabkan ketidakteraturan siklus haid. Tidak terdapat antara kesesuaian dengan fakta, yaitu walaupun mahasiswa memiliki tingkat kecemasan sangat berat namun mereka masih memiliki siklus menstruasi yang normal yaitu 21-35 hari. Hal ini bisa terjadi karena mahasiswa mampu beradaptasi dengan tingkat kecemasan yang mereka miliki dan mampu menyelesaikan masalah mereka, dan memiliki adaptasi koping positif yang baik. Disamping itu mahasiswa mendapat dukungan yang baik itu dari teman, pihak institusi atau dari keluarga. Hal ini sejalan dengan penelitian yang dilakukan oleh Lufthi \& Yaunin, (2020) bahwa tingkat kecemasan tidak berhubungan dengan siklus menstruasi bahwa hasil yang berbeda tersebut dapat dipengaruhi oleh beberapa faktor, salah satunya adalah faktor 
responden. Meskipun mahasiswa terkena faktor risiko yang sama, itu tidak menjamin bahwa semua mahasiswa akan menunjukkan respon adaptasi dan tingkat kecemasan yang sama. Selain itu, gangguan menstruasi juga dipengaruhi oleh massa tubuh, aktivitas fisik, stres, diet, dan paparan lingkungan serta kondisi kerja/belajar. Hal ini dapat menyebabkan gangguan kecemasan dengan siklus menstruasi yang teratur/normal pada responden

\section{KESIMPULAN}

Hasil penelitian menunjukkan bahwa mahasiswi yang memiliki pengalaman tidak menyenangkan selama mengikuti pembelajaran tingkat akhir, mendapat dukungan teman sebaya dapat mempengaruhi kecemasan. Sedangkan dukungan keluarga tidak berpengaruh terhadap kecemasan. Karakteristik berat badan dan aktivitas fisik juga mempengaruhi siklus menstruasi. Hasil uji korelasi menunjukkan tidak ada hubungan antara tingkat kecemasan dengan siklus menstruasi pada mahasiswi tingkat akhir Stikes Katolik St.Vincentius A Paulo Surabaya.

\section{SIMPULAN}

Hasil penelitian menunjukkan tidak ada hubungan antara tingkat kecemasan dengan siklus menstruasi pada mahasiswi tingkat akhir Stikes Katolik St.Vincentius A Paulo Surabaya.

\section{UCAPAN TERIMAKASIH}

Ucapan terimakasih kepada STIKES Katolik St.Vincentius a Paulo Surabaya, mahasiswi tingkat akhir (Prodi Ilmu Keperawatan, Keperawatan, Fisioterapi) sebagai responden dalam penelitian ini.

\section{DAFTAR PUSTAKA}

Afiyanti, Y., \& Pratiwi, A. (2017). Seksualitas dan Kesehatan Reproduksi
Perempuan; Promosi, Permasalahan dan Penanganannya dalam Pelayanan Kesehatan dan Keperawatan. PT Rajagrafindo Persada.

Afryan, M., Saputra, O., Lisiswanti, R., \& Ayu, P. R. (2019). Hubungan Tingkat Stres Terhadap Motivasi Mahasiswa dalam Menyelesaikan Skripsi pada Mahasiswa Tingkat Akhir Fakultas Kedokteran Universitas Lampung Relationship Between Stress Levels and Motivation of Students Who Completing Final Task on Final Years Stud. Jurnal Agromedicine, 6(Juni), 63-67.

Andrews, G. (2010). Buku Ajar Kesehatan Reproduksi Wanita Ed.2. EGC.

Devi, E. S., Mifbakhuddin, \& Mulyanti, L. (2015). Hubungan Antara Tingkat Kecemasan Dengan Pola Menstruasi Pada Mahasiswa D3 Kebidanan Tingkat 3 Universitas Muhammadiyah Semarang. Jurnal Kebidanan, 20-24. http://103.97.100.145/index.php/jur_bi d/article/view/1682/1733

Diferiansyah, O. (2015). Perbedaan Tingkat Gelisah antara Mahasiswa Kedokteran Tingkat Pertama yang Tinggal Kost dan Bersama Orang Tua. J Majority, 4(6), 16-18.

Dya, A. N. M., \& Adiningsih, S. (2019). Hubungan antara Status Gizi dengan Siklus Menstruasi pada Siswi MAN 1 Lamongan The Correlation between Nutritional Status and Menstrual Cycle of Female Students at Islamic Senior High School 1 , Lamongan. IAGIKMI \& Universitas Airlangga, 310-314. https://doi.org/10.2473/amnt.v3i4.2019.

Harzif, A. K., Silvia, M., \& Wiweko, B. (2018). Fakta-Fakta Mengenai Menstruasi pada Remaja. Medical Research Unit Fakultas Kedokteran Universitas Indonesia.

Hidayah, N., Rahfiludin, M., \& Aruben, R. 
(2016). Hubungan Status Gizi, Asupan Zat Gizi Dan Aktivitas Fisik Dengan Siklus Menstruasi Remaja Putri Pondok Pesantren Salafiyah Kauman Kabupaten Pemalang Tahun 2016. Jurnal Kesehatan Masyarakat, 4(4).

Kusmiran, E. (2014). Kesehatan Reproduksi Remaja dan Wanita. Salemba Medika.

Lufthi, A. S., \& Yaunin, Y. (2020). The Relationship Between the Anxiety Level and Menstruation Cycle of Female Undergraduate Students Majoring in Medicine of Andalas University in 2019. Andalas Obstetrics and Gynecology Journal, 4(1), 53-61.

Meilan, N., \& Fillona, W. (2018). Kesehatan Reproduksi Remaja Remaja: Implemetasi PKPR Dalam Teman Sebaya. Wineka Media.

Purwati, Y., \& Muslikhah, A. (2020). Gangguan Siklus Menstruasi Akibat Aktivitas Fisik dan Kecemasan. Jurnal Kebidanan Dan Keperawatan 'Aisyiyah, 16(2), 217-228. https://ejournal.unisayogya.ac.id/ejourn al/index.php/jkk

Sari, M. R. (2020). Hubungan Pola Menstruasi Dan Status Gizi Dengan Kejadian Anemia Pada Remaja Putri Di Sma Negeri 2 Tembilahan. Jurnal Kesehatan Mercusuar, 3(1), 28-36. https://doi.org/10.36984/jkm.v3i1.81

Sawitri, A. R., \& Widiasavitri, P. N. (2021). Strategi coping mahasiswa yang sedang menyusun skripsi di tengah pandemi COVID-19. Jurnal Psikologi Udayana, $8(1)$, $78-85$. https://doi.org/10.24843/JPU.2021.v08. i01.p08

Sinaga, E., Saribanon, N., Suprihatin, Sa'adah, N., Salamah, U., Murti, Y. A., Trisnamiati, A., \& Lorita, S. (2017). Manajemen Kesehatan Menstruasi. Universitas Nasional IWWASH Global One.
Sudarya, I. W. (2014). Analisis FaktorFaktor yang Mempengaruhi Stres pda Mahasiswa dalam Penyusunan Skripsi Jurusan Manajemen Undiksha Angkatan 2009. E-Journal Bisma Universitas Pendidikan Ganesha Jurusan Manajemen, 2, 1-10.

Sutejo. (2019). Keperwatan Jiwa (Konsep dan Praktik Asuhan Keperawatan Kesehatan Jiwa: Gangguan Jiwa dan Psikososial. Pustaka Baru Press.

Wahyuni, S., Basri, G., Vitayani, S., Multazam, A., Alwi, M. K., Djafar, N., Pascasarjana, D., Muslim, U., Gnrh, H., \& Atlet, S. H. (2018). Pengaruh intensitas olahraga terhadap kadarhormon Gnrh (Gonadotropin Releasing Hormon) Pada Siklus Haid Altet Di Pusat Pembinaan Latihan Pelajar Makassar. UMI Medical Journal (UMJ), 3(2), 1-14. https://jurnal.fk.umi.ac.id/index.php/um imedicaljournal/article/view/43

Wirenviona, R., \& Riris, I. D. C. (2020). Edukasi Kesehatan Reproduksi Remaja. Universitas Airlangga. 